\title{
Changes in the identity of the teaching profession: A study of a teacher union in Sweden from 1990 to 2017
}

\author{
Joakim Krantz ${ }^{1}$ (D) $\cdot$ Lena Fritzén ${ }^{2}$
}

Accepted: 3 May 2021 / Published online: 24 May 2021

(C) The Author(s) 2021

\begin{abstract}
We analyse changes in the collective identity that Sweden's largest labour union for teachers had during the period 1990-2017. The study is based on theory about how collective identity is constructed in adaptation and resistance to external categorical dimensions and internal group identification. We identify shifts in relation to how the union employ different aspects on teachers' recognition, emotional engagement, and evaluation. Two clear cut-off points can be identified. The first point, which is clearly related to the impact of political reforms, took place in 2000 and is about increased demands with respect to transparency, legality, equality, efficiency, and attainment results. The second point took place in 2015, a year when Sweden confronted a new set of social challenges. The teaching profession was re-launched as a moral agent and in need of a trust-based steering approach.
\end{abstract}

Keywords Teachers unions $\cdot$ Collective identity $\cdot$ Discursive shifts $\cdot$ Professionalism

\section{Introduction}

The conditions for the teaching profession have undergone a number of drastic changes in Sweden during the past 30 years. During this period, the Swedish school system was subject to a number of reforms and changes in policy. On a more general level, these reforms and changes in policy entailed that, during this period, the

Joakim Krantz

Joakim.krantz@lnu.se

https://nu.se/en/staff/joakim.krantz/

Lena Fritzén

Lena.fritzen@1nu.se

https://lnu.se/en/staff/lena.fritzen/

1 Department of Education and Teachers' Practice, Faculty of Social Sciences, Linnaeus University, Pelarplatsen 1, 35195 Växjö, Sweden

2 Department of Pedagogy and Learning, Faculty of Social Sciences, Linnaeus University, Pelarplatsen 1, 35195 Växjö, Sweden 
Swedish school system moved from a centralised system of control to a decentralised goal- and result-driven system of control, with a number of attendant consequences for teachers' work. Studies have shown that the identity of the individual teacher changed during the above-mentioned period (Krantz \& Fritzén, 2013, 2017). We thus ask: What happens to the teachers' collective identity when extreme changes are so far-reaching, as they have been these past decades in Sweden? According to Jenkins (2014, p. 113), assuming a point of departure in collective identities, group identification, and group categorisation have "practical consequences" which we argue must be empirically investigated. For this purpose, we turn to the Swedish Teachers' Union [Lärarförbundet, henceforth "STU"], since the union is an important actor in the process of creating a group identity which, in turn, informs the teachers' collective identity (Bascia, 2008; Lilja, 2014; Popiel, 2013). Our decision to analyse STU is based on the fact that the union is the largest trade union for teachers in Sweden and is primarily an organisation for teachers who work in the compulsory school education system in Sweden. For the period 1990-2017, we investigated how STU by means of its public image and group identification in the magazines that it distributes to its members chose to discuss, defend, and support the changes which STU members were subject to in their professional lives. We adopt the perspective that the creation of a professional identity takes place in the field of tension between adoption and resistance, that its creation takes place discursively, and that the collective identity is created in the interaction between the teachers' union's collective internal group identification and the teachers' union's response to external categorisation (Jenkins, 2014). We examine how the union produces and reproduces discourses of collective identities and how they are made manifest in the context of editorial texts, discursive practices, and the social practice within which the union is embedded (Fairclough, 1992). Our analysis is based on the theory of professions and what this theory addresses in terms of different dimensions of professionalism (Agevall \& Jonnergård, 2007; Agevall et al., 2017; Evetts, 2009; Evetts et al., 2006; Freidson, 2001).

The aim of this paper is to identify the changes in the collective identity as they appeared in the STU teacher union during the period 1990-2017.

Our starting point for this study is based on the observation that a discourse of collective identity "isn't 'just there', it's not a 'thing', it must always be established" (Jenkins, 2014, p. 18).

\section{Political and educational developments in Sweden from 1990 to 2017}

The teaching profession underwent a number of radical changes during the abovementioned time period in the wake of the introduction of New Public Management (Solbrekke \& Englund, 2011). A number of divergent opinions exist regarding the effects that these changes produced in terms of "professionalisation" and even "de-professionalisation" (Mausethagen, 2013; Mausethagen \& Smeby, 2016). One of the leading causes behind these changes is often presented as a result of the decentralisation of the school system and the reforms that were implemented in the 1990s with respect to the deregulation of the Swedish school system (SOU, 
2014). Municipalities across Sweden took over responsibility for the financial management of the schools within their respective geographical areas. In 1992, public financing for independent schools was introduced, as well as a system of individual school vouchers (Jarl \& Rönnberg, 2010). Quantitative goals, results-evaluations, and individualised- and performance-based plans were progressively internalised and normalised in a market-place oriented approach to the welfare system. There was a gradual change from a "control system" that was based on rules and regulations, to a "goal- and result-orientated control system", resulting in an increased degree of bureaucratisation (OECD, 2015). For the teachers, this overall change entailed a change in responsibility, especially with respect to how the quality of their work became subject to more controls and checks than what was previously the case (Bergh, 2010; Carlbaum et al., 2014; Ivarsson Westerberg, 2016; Krantz \& Fritzén, 2017).

The lack of equality between different schools in Sweden is another issue. The difference in academic performance results between schools doubled between 2000 and 2016. There is disagreement concerning the cause behind this increasing level of disparity in terms of equality, however. Some people claim that the free-school reform allows socio-economic aspects to play a more significant role with respect to school segregation (Trumberg, 2018). Others claim that some schools' performance levels (or lack of) are related to the increasing number of students with a foreign background who have entered the school system (Gustafsson et al., 2016). When the so-called "refugee crisis" occurred in 2015 in Europe, approximately 70,000 schoolaged children applied for asylum in Sweden, of which, 20,000 students received residency in Sweden. For some local authorities, this entailed a 20-50\% increase in the number of children in the schools that they were responsible for SKL (2016). In addition to changes in management principles, and a lack of equality, the Swedish school system is currently confronted with worsening school performance and a severe shortage of teachers (SKL, 2018).

We begin our investigation of STU in 1990, i.e. quite soon after the progressive establishment of New Public Management (NPM) in Sweden's official management policies. In more recent years, criticism has been directed against the effects that this change in management system has had on a variety of professions. In the areas of healthcare, education, and the private sector, for example, NPM models have been met with ever-increasing opposition (Agevall, et al., 2017; Bejerot et al., 2015; Bogotch et al., 2007; Brown \& Calnan, 2016; Evetts, 2010). This opposition, amongst other things, was given political support by the Swedish government in the form of The Delegation for Trust-Based Public Management (Bringselius, 2018), which was tasked to identify and promote conditions conducive to a more trustbased management system. It is against this background of changing leadership and management systems that the teachers' union found itself during the period mentioned above. 


\section{How the union is embedded in social practice}

In Sweden, there is a long tradition of strong labour union representation of public sector employees. The unions are expected to satisfy their (voluntary) members' demands and expectations. Consequently, an individual union's strategies may not radically diverge from what its members' want, since this would pose a risk to its internal legitimacy (Popiel, 2013). "Legitimacy", in this case, is a question of how symbolic, collective professional identities correspond to (or stand in contrast with) action-oriented, individual professional identities (Heggen, 2008). With respect to the teaching profession in Sweden, it has found itself in a position of uncertainty regarding issues concerning its knowledge base, status, and legitimacy for a long time (Carlgren \& Marton, 2001; Nilsson-Lindström \& Beach, 2013). This feeling of uncertainty can be found within teachers' unions, too (Lilja, 2014). From a professional perspective, specific political reforms (such as the 1990s increased decentralisation of responsibility) can be motivated by the idea that such reforms assist in securing the teaching profession's status. Research has shown how teacher unions often adopt the goals of "professionalisation" which are initiated by politicians (Bascia, 2008; Evetts et al., 2006; Jesson \& Simpkin, 2007). To claim a certain level of autonomy, status, and the idea that the teaching profession possesses a level of professionalism which makes the education system effective, STU must demonstrate that teachers share values that are in harmony with these political reforms (Carlgren \& Marton, 2001; Krantz \& Fritzén, 2013; Lilja, 2014). Since the union strives to achieve and maintain both internal and external legitimacy, it needs to be able to establish and uphold a qualitatively good standard of teaching, and remain active with respect to international educational performance measurements, for example. This raises questions about the strategic priorities that the union must make. Should the union focus on strengthening its communicative abilities and on its efforts to show itself in a good light, or should it focus on strengthening its analytical investigatory capacity and its ability to understand the government's political goals? In the materials that we investigated, we note that both of these strategies are represented.

One can also question the number and nature of the opportunities that the teacher's union's press media enjoyed (given its limited resources) to report on properly, follow up on, and initiate its own political agenda (Jacobsson \& Pierre, 2008). The creation of a collective identity has to take place against this backdrop, and, in our estimation, in a discursive battle between several parties with respect to the type of knowledge and the values which the professionals' work should be based upon (Nerland \& Karseth, 2015; Scott, 2008). Sachs (2001) observes:

What constitutes a profession and so on have been sites of academic and ideological struggles between union leaders, bureaucrats and academics that are currently being played out in a variety of settings. (Sachs, 2001, p. 150)

In this regard, we argue that the STU, in its trade press, created a group identification and self-presentation in the form of a discursive collective identity.

Based on this understanding of the concept of "collective identity", we find that the teachers' unions (during the period under discussion) were forced to navigate 
a situation where leadership and management systems were subject to continual change (Carlgren, 2000; Jesson \& Simpkin, 2007; Klette, 2002; Nerland \& Karseth, 2015; Persson, 2007; Sjöberg, 2010).

The editorial articles which we analysed were texts which create (whilst being simultaneously subject to influence from) continual political, ideological, economic, and cultural changes in social practices in Sweden. These texts were produced, distributed, and consumed in a specific social context where the union intended to present its own membership, but also influence the opinions of its membership and the general public (Fairclough, 1995). We thus note that it was during a period of intensive policy production that influence was brought to bear on the discursive practice within which the teachers' collective identity was formed (Krantz \& Fritzén, 2013).

\section{Teachers' magazines as a basis for analysis}

For the purpose of this paper, we examine the largest teachers' union in Sweden, namely Lärarförbundet. However, it should be mentioned that two teacher unions operate in Sweden, each with a partially different approach to political issues that touch on education (Lilja, 2014). Our decision to analyse STU is based on the fact that the union is primarily an organisation for teachers who work in the compulsory school education system in Sweden. The texts which were analysed for this study were taken from Lärarnas tidning ("The Teachers' Magazine" [TM]) and Pedagogiska magasinet (The Pedagogic Magazine [PM]), which are sent out to the members of STU. TM is Sweden's largest trade news magazine for teachers. The degree to which members read their trade press is an indication of how closely connected they are to their union. In a comparative study, it was shown that women, older employees, public servants, and primary school teachers read their respective trade presses more often than the rest of the population (Brante et al., 2015). In 1990, TM had a circulation number of 180,000 , and in 2017 , this number was 223,000 . TM published 626 editions between 1990 and 2017. For the present study, articles were chosen from each of these editions. The publisher is appointed by the union's management team so as to ensure that the editorials which are published are in accordance with the union's editorial program (TM, 2010, nos. 1 and 3; Lärarförbundet, 1995). $P M$ has the aim of improving the relationship between the school system and current research and is issued four times each year. With the publication of the PM, STU wishes to stimulate teacher professionalism and encourage teachers to engage in the debate about the school system. Furthermore, STU has the ambition to highlight the ongoing pedagogical debate and current research and create a meeting place for teachers, researchers, and decision-makers (TM, 1994, no. 18; 1995, nos. 10 and 26). The decision to publish the PM should be seen as a call for mobilisation from the union in response to the external pressure on teachers "to develop their professional thinking". (TM, 1996, no. 3). Eighty-eight editions of this magazine were analysed, covering a period from 1996 to 2017. All of the editorials published in these magazines were included in the present study, whilst the other reports and journalistic material found in the magazines were not included in our study. 


\section{Theoretical point of departure}

The ontological starting point for our study is based on the sociologist Richard Jenkins's (2014) theory that the creation of a social identity takes place in social practices via the processes of adaptation and/or resistance to prevailing external conditions. The methodology that we employ is based on the idea that "collective identity" can be understood in terms of how it is created, re-created, and how it changes within "orders of discourse" (Fairclough, 1992). The analytical epistemological tools that we make use of are primarily taken from the theory of professions (Agevall et al., 2017; Evetts, 2009; Friedson, 2001).

\section{The construction of collective identity}

Our ontological claim is that the construction of a collective identity, as formed in the union trade press, is a discursive social practice (Fairclough, 1992; Jenkins, 2014). Jenkins (2014) argues that during the formation of a social identity, a dialectic between internal and external aspects is instantiated. Assuming this point of departure, we propose that the teachers' union's group identification is an ongoing process which, in terms of a collective identity, is constructed in adaptation and resistance to external categorical dimensions and internal group identification. Note how Jenkins (2014) also formulates a distinction between nominal and virtual identity:

Collective identification also has nominal and virtual dimensions. The nominal is how the group or category is defined in discourse, the virtual how its members behave or are treated. [...] In practice they are chronically implicated in each other, but there is no necessary agreement between them [...] Collective internal definition is group identification; collective external definition is categorisation. (Jenkins, 2014, p. 111).

In the present study, the nominal dimension (as per above) is made manifest in how STU adapts or shows resistance to policy changes, whilst the virtual dimension addresses how STU claim that their members experience and are treated by prevailing changes in policy. By analysing the field of tension between the nominal identity (external categorisation) and the virtual identity (group indentification), we reveal the points of congruence and points of disagreement in STU's discursive construction of collective identity. Note that we cannot make reference to individual identities, even though it may be reasonable to assume that an individual teacher's identity is, to a significant degree, constructed from the collective identity.

\section{Critical discourse analysis}

We examine media discourse which includes ideological processes and how they are transformed in a dialectic fashion between texts (the editorials that were examined), discursive practices, and the social practice within which the union is embedded 
(Fairclough, 1992). In our analysis, we compare and evaluate different representations of collective identity, so as to identify "what they include and what they exclude, what they foreground and what they background" (Fairclough, 1995, p. 47). Informed by critical discourse analysis, we are also enabled to identify "inconsistencies and selfcontradictions in the media text" (Schrøder, 2012, p. 116; Chouliaraki \& Fairclough, 1999). Critical discourse analysis (CDA) allows us to come to an understanding of the changes in language use which appear in the union's publications and how these discourses influence, and are influenced by, the collective identity of the time.

\section{Conditions for the teaching profession}

During the time period under investigation, a functional view of the sociology of the profession (Freidson, 2001; Parson, 1939) gave way to a more neo-liberal understanding of the profession's role and significance (Brown \& Calnan, 2016; Fournier, 1999). Evetts et al. (2006) discuss this movement as instantiating two ideals; as one moves from a functional view to a neoliberal view, the relevant ideals are spoken of in terms of occupational professionalism and organisational professionalism, respectively. Occupational professionalism "is based on autonomy and discretionary judgement and assessment by practitioners in complex cases. [...] Controls are operationalised by practitioners themselves who are guided by codes of professional ethics" (Evetts, 2009, p. 23f.). Agevall and Jonnergård (2007) and Agevall et al. (2017) discuss aspects of occupational professionalism in terms of "recognition", "emotional engagement", and "evaluating and taking responsibility for one's own work". Each of these three aspects is dependent on each other. Recognition refers to the ability to identify what is demanded by a professional person in a particular situation. Recognition is summarised as a perceptual ability which is grounded on knowledge, experience, and ethics. Emotional engagement refers to the subject's willingness to do a good job. It is closely related to whether a teacher, for example, can make independent choices or not. In this context, we note that teacher autonomy entails that a teacher enjoys freedom of action and possesses the ability to act. Evaluating and taking responsibility for one's own work involves the critical examination of one's work and taking personal responsibility for such work as an inalienable part of knowledge development (Agevall et al., 2017; Krantz \& Fritzén, 2017). Organisational professionalism is a discourse "of control used increasingly by managers in work organisations [...] It relies on externalised contrast to occupational professionalism forms of regulation and accountability measures such as target-setting and performance review" (Evetts, 2009, p. 23).

Sachs (2001) makes similar claims about two discourses with respect to teacher professionalism. The one discourse is "managerial professionalism", which is characterised by an entrepreneurial identity, whilst the other discourse is called "democratic professionalism", which is based on an active identity where the teaching profession takes on greater social responsibility.

The perspectives delineated above with respect to the profession's conditions and professionalism are relevant to our analysis in terms of how the collective identity is formed in a framework where certain fields of tension are operative. 


\section{Discursive shifts in the collective identity}

The period under investigation has generally shown itself to be a transformative period for the union and the teachers' collective identity. However, we are able to identify three significant time periods; namely, 1990-2000, 2000-2015, and 2015-2017 (Krantz \& Fritzén, 2013). Our analysis shows that the first period is characterised by decentralisation, deregulation, and goal-driven control. During the second period, we observe an increase in national and international control, inspections, and various performance metrics, which resulted in an even stronger goal-driven control and increased demands for documentation (Agevall et al., 2017; Krantz \& Fritzén, 2017). The third period is characterised by a number of changes in social practices, including an increase in social polarisation which primarily is made manifest in the Western world in terms of nationalism, xenophobia, the movement of refugees, the \#metoo movement, general distrust, and denial of scientific reasoning. With regards to the Swedish context, we note an increase in criticism of NPM, something which was taken up by the teacher's union too. In the following section, we discuss the three above-mentioned periods in terms of distinct shifts in the collective identity.

\section{Teaching, professional responsibility, and trust (1990-2000)}

The idea that there exist internal power struggles and tensions between pedagogic-, didactic-, methodological-, and subject-theoretical competence is repeatedly touched on by STU. The claim that a teacher's competence and professional knowledge are "generalist" was a dominant and unquestioned component of the collective identity up until the early 2000s. During the first part of the time period, a teacher's didactic abilities and the practice of teaching others to learn (pedagogy) were guiding principles with respect to an integrative, co-operative collective identity:

A teacher's professionalism is found in their ability to adapt their knowledge of the subject to the target group which they will address and in their ability to co-operate with their colleagues. (PM, 1996, no. 4)

At the beginning of the period under investigation, STU had placed great hope on the curricula reform that had been implemented in the early 1990s. In a goal- and result-orientated system, the union saw an opportunity for teachers to take on greater responsibility for the structure and development of the school system. It was claimed that "[an] evermore professional teacher corps [would] take independent responsibility for the school system's quality and development." (TM, 1994, no. 26). However, according to the union, it was soon shown that it was not the teaching profession per se which had been granted the power, freedom, and capacity to act, but rather it was the case that "the increased freedom was often occupied by municipal representatives-politicians, officials, and contracted consultants.” (TM, 1998, no. 9).

The union reported on the introduction of a number of reforms at the beginning of the 1990s, which were intended to strengthen the teachers' sense of autonomy. At 
the same time, an adaptation in the collective identity took place in response to the external challenges which emerged in social practices, with a process of externalisation as a result of this. A point of difference emerged between (1) how STU interpreted the political reorganisation of school governance and control and (2) how the union claimed the consequences of this was for teachers, which formed the basis of a collective identity which was sceptical of the municipality's governance role in the school system.

STU claimed that there existed "a historical assignment to not only provide knowledge but to [also] satisfy all of the students' needs" (TM, 2001, no. 8). The union warned against the "exam and test hysteria" (that had emerged in the UK and the USA) which forced teachers to spend more time on evaluating students than planning for their lessons (TM, 1993, no. 2). At the beginning of the period, STU was wary of a culture which would lead to "teaching to the test". The union claimed that they were "cautious of competitions and measurement methods which were provided by actors outside the school system" (TM, 1996, no. 7). They were also critical of the idea that the then-current grade system, rubrics, different grade levels, and the number of tests would "lead to a strictly controlled school system where measurable outcomes are central" (TM, 1994, no. 7). The collective identity was characterised by the notion that each student's needs were to be satisfied by means of a holistic, care-orientated approach to teaching.

STU expressed an ambivalent opinion concerning the input and output-orientation that was then manifest in the governance of the school system. On the one hand, the new curriculum (from the middle of the 1990s) could be interpreted as being input-oriented, which allowed "the teacher's professional creativity [to] run free" (TM, 1995, no. 4). On the other hand, the union warned that power over the school system's goals would lie with an output-orientated "exam control system".

Parallel with devolution, a centralisation has taken place however. Detailed goals with respect to grades and course plans can result in a situation where the school system is micro-managed more effectively than what it was under the old system. (TM, 1995, no. 26)

A one-sided output-orientation approach does not take into consideration the different conditions which the school system operates under. To take these different conditions into account, STU claimed that "[a] school's operations will be formed in practice to those who are closest to those operations-in the case of a school, its teachers, headmaster, students, and parents" (PM, 1996, no. 3). STU then positioned itself as being against a school model with state-funded education inspectors who just made "blitz inspections", by emphasising the importance of a body of inspectors who could "follow the school's operations for a longer period of time" (TM, 1997, no. 6) instead. 


\section{Summary reflection}

During the 1990s, there existed a sense of trust and hope that the devolution of the school system would lead to a process of professionalisation where the teaching profession's knowledge-base and experience would be the driving forces (Freidson, 2001). This identity gradually faded away as the profession's competence and knowledge-base were brought into question more and more. This situation can be interpreted where the external policy changes successively influenced the teachers' collective identity with regards to what constituted the teachers' recognition, emotional engagement and evaluation, and their taking responsibility for their own work (Agevall et al., 2017).

During the 1990s and at the beginning of the 2000s, it was claimed by STU that the teachers' engagement and motivation to do their work had emerged from a common pedagogic point of view, a collegial professional responsibility, a professional code of ethics, and from a sense of altruism (Evetts, 2009). However, during this period it became apparent within the collective identity that, in fact, it was teacher differentiation, specialisation, and career opportunities which were the actual motivating forces behind the teachers' engagement and desire to develop in their profession.

Already by the 1990s, the teaching profession's internal quality assurance criteria had been subject to the growing challenge of an external quality assurance and control discourse (Bergh, 2010). This external discourse resulted in a collective identity which was informed by circumstances where the trust and legitimacy in the teachers' own ability to evaluate the quality of their work were undermined. The collective identity thus had to adapt to an external categorisation and structural frameworks which dictated that teachers were subject to what other people had decided (Jenkins, 2014).

\section{Administration, regulation, and external demands (2000-2015)}

The union gradually argued for a more subject- and evaluation-oriented collective identity, where "a good teacher puts knowledge first" (TM, 2007, no. 16). This shift towards the notion of the "specialist" is primarily a manifestation of a striving for status and efficiency in terms of a (re-)distribution of responsibility, where "someone takes on special responsibility for the development of mathematics, another is a specialist in Swedish, [another], who is not a teacher, is an administrative professional" (TM, 2010, no. 4).

A teacher should seem to be the specialist he or she is. A teacher should no longer do everything and be a diverse employee. This does not benefit the teacher's central assignment. (TM, 2010, no. 8)

The argumentation behind the shift in perspective regarding the teacher's professional role was based on the notion that "every student must have the right to meet with teachers who are specialists in their subject, even during the early-primary 
stages and pre-school." (TM, 2008, no. 13). An increase in teacher differentiation thus became all the more critical with respect to the collective identity, and teacher differentiation was presented as something which the profession would benefit from in terms of increased salaries and status:

Differentiation within the profession needs to increase, with respect to [the teaching] assignment, responsibility, and salary. This is necessary if we are to attract top students to the profession and to get more skilled and experienced teachers to remain [in the profession]. (TM, 2016, no. 7)

The arguments in support for "differentiation" and "specialisation" also became part of the criticism that was directed at an increased administrative workload. The fact that teachers were forced to perform a variety of administrative tasks instead of spending the majority of their time actually teaching became a part of their collective identity. This point of criticism was articulated all the more clearly by the teachers' union as a form of resistance to NPM and the move towards centralised control of the school system.

According to STU, "an increase in bureaucratisation and more decision-making hierarchies in the school system" (PM, 2001, no. 1) diminished the teachers' autonomy and status. The disappointment that was felt over the fact that teacher autonomy was not strengthened but, instead, was successively taken away from teachers became a central and critical part of how the union informed the teachers' collective identity.

The pursuit for internal quality criteria was confronted by an ever-increasing number of external demands made by politicians, parents, and students. A shift in the collective identity occurred, from strengthening the profession to strengthening the efficiency and governance of the school system. Simultaneously, the governance systems that were in place at the time were considered to be all the more arbitrary and based on a lack of trust in the teachers. The previous years of too little political responsibility and the rapid pace of reform had, according to STU, limited the teachers' professional autonomy and had caused an administrative overload (TM, 2013, no. 13). Thus, the profession had to clearly "show the consequences" of being "forced to do the wrong things" (TM, 2013, no. 8).

Gradually, an evaluation practice became well-established in conjunction with talk of an "evidence-based pedagogy" as part of the collective identity. "If you want better results in the Swedish school system, then research on what works and what is needed in the Swedish school system is crucial." (TM, 2010, no. 3). In parallel to a more care-oriented discourse, it was emphasised by the union that knowledge and the awarding of grades must be taken very seriously (PM, 2016, nos. 2 and 4).

It was reported that the results of international student performance evaluations (Timss, Pirls, and PISA) reflected a serious state of affairs for "the development of our country" and for every student's "chance in life" (TM, 2014, no. 19). This was argued at a time when Sweden's position in the PISA rankings fell considerably. For teachers, this situation entailed increased demands regarding documentation, planning, following-up on their students, and student performance evaluation. After the international performance evaluations made by PISA were published, the union claimed that "all work assignments which did not lead to better results and higher 
quality must be questioned and removed", because "Sweden cannot afford to spend time on things which do not improve the students' results and the school system's quality." (TM, 2013, nos. 9 and 12). When the Swedish PISA results were in decline, the union highlighted the prevailing conditions for the teachers' work, in terms of a lack of qualified teachers, the difficulty faced in retaining teachers, and inadequate professional development. The union argued that if the international rankings were to be improved upon, then what was needed was not more "unreasonable regulations" but, preferably, a more considerable degree of autonomy for the teachers and an improvement in providing "opportunities for more knowledge" (TM, 2014, no. 9).

To maintain the union's external legitimacy, STU adopted increasingly more focused reasoning with respect to "quality", "efficiency", and the "knowledge economy". As a consequence of this, these concepts became all the more incorporated into the collective identity. The union was drawn into an evidence-based discourse in response to the decrease in student performance on international comparison tables.

The establishment of fewer (but clearer) attainment goals was, however, considered to be a problem because it was felt that a limited number of attainment goals might influence the prevailing attitude towards learning in the school system. It was feared that attainment goals which were easy to measure would supersede the school system's democratic assignment.

Besides providing students with knowledge, the school system must also provide students with the fundamentals which are needed to function in a democratic society. (TM, 2006, no. 4)

During large parts of the period under investigation, the collective identity was influenced by a perspective that was dominated by summative learning, with the result that the complex context wherein learning takes place was assigned to a subordinate position. There was, however, an apparent resistance against this approach, as expressed in articles in both $T M$ and $P M$. In this regard, the teachers' enthusiasm and the quality of teaching were thought to have been affected negatively.

There are a good number of teachers who lose their enthusiasm because of the control and measurement systems which are being established in the school system. There will not be better quality just because one has measured many times. (TM, 2006, no. 3)

The union showed both resistance against and adaptability towards a simplified, short-sighted, and predictable perspective towards learning and educational attainment. It became gradually more and more difficult for the union to resist a discourse of "measurable learning" which placed "objectivity", "equality", and "efficiency" at the centre of its argumentation. At the end of the period under investigation, this criticism became more explicit, and it was claimed that "the pendulum had swung too far the other way" (TM, 2013, no. 2). 
Today's educational policies are controlled by an anxious examination of attainment measurements and international rankings, by a naïve trust in 'power language' and 'simple' solutions. (PM, 2012, no. 3)

The union also addressed the problem of the large number of teachers who were leaving the profession because of the large number of national exams that were being administered. The national exam system at the time entailed that teachers had to spend a significant amount of time on collating results and setting grades. The union judged this development to be counterproductive because "exams reduce the students' level of knowledge instead of increasing them, because the teachers don't have time for their lessons" (TM, 2013, no. 19). The union claimed that complex learning and educated citizens were necessary if people were not to be reduced to an "interchangeable production element" in a "well-oiled machine for economic growth" (PM, 2012, no. 4). Whilst ever-increasing numbers of students were excluded by an education system that was all the more focused on measurability, voices were raised to call for more inclusion in response to the challenges that society faced at the time.

The union argued for increased power and increased levels of participation on the part of the teachers, and for a system where the teachers could perform self-evaluation (TM, 2004, no 4).

However, a regime of "strict school inspection[s]" (TM, 2010, no. 19) would, in effect, establish a national quality assurance system which the union had requested. According to the union, many teachers suffered from "stress on their conscience" (TM, 2014, no. 19) as a result of the out-put orientation and a perceived imbalance between responsibility, abilities, and resources. The problem was not that the teachers lacked the ability to take action, but rather, they lacked the freedom to take action.

\section{Summary reflection}

On the one hand, the union requested the implementation of a more efficient national quality assurance system so as to ensure educational equality, but, on the other hand, it articulated a concern over a lack of resources to deal with the demands that such an out-put orientation would entail.

In step with devolution and the opening up the school system to market forces, other actors appeared on the scene and claimed that they possessed knowledge of what was best for the school system. We thus observe that the collective identity was shaped by a process of externalisation. In other words, what took place was a re-prioritisation, to the benefit of what was construed as organisational professionalism (Evetts, 2009). Notions of "knowledge" and "competence", under these circumstances, focused on teachers doing things in the right way and being good at paperwork, marketing, and technical support. A gradual shift in goals took place, which undermined the teachers' ability to receive recognition for the teaching work that they performed (Agevall et al., 2017). 
Because of the insistence of result-driven management systems during the 2000s and 2010s, attention was directed towards "measurable results". Less time was available to exploit one's knowledge with respect to planning, delivering, and evaluating qualitatively good lessons. Proven teaching experience becomes less accessible when knowledge is verbalised, documented, and changed so that it can be subject to evaluation and measurement (Krantz \& Fritzén, 2017). The collective identity at the time ran the risk of losing its foundations of tested teaching experience and thus its ability to make professional judgments. As student performance results declined, it became difficult to defend the status quo (Blomgren \& Waks, 2009). In the collective identity, there emerged a need for specialisation, which became a further argument for qualifications and career opportunities (Lilja, 2014).

Teachers were expected to demonstrate transparency in their work, and so a gradual shift took place towards a "system rationality' which impacted on the teachers" emotional engagement in different ways. The union was saddled with a particular discourse which was characterised by "efficiency", "comparability", "transparency", "regulations", and a demand for increased "documentation" (Evetts, 2009). These demands resulted in a lack of trust. In this situation, the collective identity was shaped by the fact that teachers had begun to work in a way where they could keep their noses clean. Consequently, their degree of emotional engagement waned (Jonnergård \& Krantz, 2017). The union reported that many teachers had "run out of steam" because of the regulatory and measurement systems that they had to follow. According to STU, teachers were forced to perform work which did not correspond to their experience, their expectations, their competencies, or their knowledge base.

STU argued that many teachers found themselves in a situation where their enthusiasm for a career in teaching had decreased to a dangerously low level. Teaching and establishing relationships with colleagues and students had been pushed to the side, and, in their place, measurable outcomes and documentation had become central features of their working day. Work priorities changed as a consequence of this state of affairs, which, in turn, impacted negatively on the sense of meaningfulness and relevance of the work being done (Jonnergård \& Krantz, 2017). The job was described as "boring", fewer people wanted to become teachers, and more teachers left the profession.

The conditions for pedagogic practice and related processes were subordinate to a quality assurance discourse; a situation, claimed STU, which negatively impacted on the teachers' ability to plan and execute qualitatively good teaching (Agevall et al., 2017). In discussions concerning professional responsibility, it was also argued that teachers could not be made responsible if they did not simultaneously have the necessary authority and influence over how resources were distributed. An imbalance between responsibility, authority, and resources was thus put in the spotlight. According to STU, the political view and the professional view on "quality" stood in opposition to each other. 


\section{Societal challenges and the need for shared values and norms (2015-2017)}

At the end of the period which we investigated, when STU discussed the need for professional development, it did so in a manner that was more general than what was considered suitable with respect to the political and social situation of the time. For example, arguments that included reference to the influx of immigrants into the country, the results of the American presidential election (so-called "post-truth politics"), and the \#metoo-movement were used in the context of critical thinking, and critical approaches to norms (TM, 2015, nos. 14 and 15; TM, 2017, no. 3; PM, 2017, no. 4). We thus observe that in a time of social unease, a generalist approach reemerged in the collective identity.

At the end of the period the prevailing idea was that, in times of social unease, teachers should "support and encourage colleagues" because professional development is "for everyone's sake-not at each other's expense" (TM, 2016, no. 7). The mantra "Don't blame the teachers" became a part of a collective identity which was characterised by a sense of powerlessness in relation to the prevailing system-related conditions:

During the last few decades, the school system has developed into some form of experimental workshop for the continual evaluation- and reporting demands set by New Public Management. The results of this has been that us teachers and school leaders must spend valuable time on documentation and acting as bureaucrats - time which could have been spent on the students' learning. (TM, 2017, no. 12)

According to STU, the teaching profession was not paid heed to and consequently its influence and power diminished. For a long period of time, a process of externalisation took place, where "politicians, economists, and other self-appointed experts have engaged in a tug-of-war over who has the most and the best ideas about how the school system can be improved." (TM, 2017, no. 4). The challenge that the teaching profession was faced with was that "[e]very time a decision is made which touches on educational policy, politicians must ask themselves: Does this decrease the level of trust in teachers?" (TM, 2014, no. 19). The collective identity which was created at this point by the union was informed by the idea that it was the politicians' responsibility to establish trust for the teaching profession.

According to STU, it was clear that something had to be done to strengthen the professional autonomy of the teachers. The union appealed to the politicians to provide the teaching profession with respect and trust. We thus observe that the field of tension between "autonomy" and "externalisation" was primarily characterised by a sense of impotence with respect to "autonomy" and a certain degree of adaptation with respect to "externalisation".

The above shift in focus took place in the collective identity during the last few years of the period and was related to the political situation in the country at the time. Given these circumstances, the union argued that there existed a need for a more socially-integrated and care-oriented school system. 
The failure in the school system has divided Sweden. Hate and xenophobia have grown at the same pace as the decrease in student performance results and equality [...] The school system and education are key to society's sense of community. Us teachers hold this key. (TM, 2014, no. 14)

In step with an increase in the prevalence of xenophobic attitudes in Swedish society, the school system had become increasingly characterised by inequality, all the whilst it was subject to an influx of immigrants. In this social and political context, the union argued that every teacher was expected to be a role model and to work with questions that were related to social values $(P M, 2015$, no. 4) by always championing "every person's equal value, democracy, and freedom" and by standing against "insults, xenophobia, and intolerance". (TM, 2015, no. 17).

\section{Summary reflection}

By the end of the period, a more explicit caring role was assumed by the union, a role which was intended to create "safe places" for the students. In the collective identity, this compensatory, caring role is indicative of an orientation towards society's sense of community, with emphasis on communication, changes in perspective, openness, and symmetry. At this stage, the collective identity featured the notion that learning transcends that which can be measured and acknowledged that complex learning plays a role in a democratic society. Sachs (2001) calls this approach "democratic professionalism". The collective identity took shape in the resistance shown by the union against the increasing influence of systemrelated conditions, in terms of structures focused on control, measurability, and the desire to have an education system that would run like a well-oiled machine. Furthermore, STU claimed, a large number of students were stigmatised by the increasing influence of system-related conditions and felt excluded from the education system.

The question about what knowledge was needed so as to do the right thing during the last few years was more clearly linked to social challenges. From this perspective, social values such as tolerance and solidarity became more important than measurable knowledge - a state of affairs which placed different demands on a teacher's professional judgement (Sachs, 2001).

Thus, against this background at the end of the 2010s, we observe a change in the collective identity. In opposition to the quality assurance- and evaluation discourses', changes in social practices placed pressure on the school system (Biesta, 2011; Krantz \& Fritzén, 2017). In such a situation, STU claimed that the teachers' engagement and their ability to act as role models for shared values and democracy was of importance (Sachs, 2001). The teachers' emotional engagement, responsibility, and recognition were emphasised.

The union also maintained that whilst teachers provided qualitatively good teaching, their work was not valued and was not visible to outsiders. Gradually, the union's criticism of the prevailing regulatory and management system's 
effects on the teaching profession became more strident. At this point, norms and values became more important conditions for the development of the teaching profession. The difference between the nominal identity and the virtual identity was all the more accentuated (Jenkins, 2014).

\section{Conclusions}

We claim that two distinct cut-off points can be identified with respect to changes in the collective identity, as presented by STU. The first point in time, which is clearly related to the impact of specific political reforms, took place in 2000 . The second point in time begins in 2015-a year when Sweden was confronted with a new set of social challenges.

Up until the beginning of 2000 , the collective identity was formulated primarily from a functional view; in terms of the sociology of the profession with respect to the profession's "exclusivity", "autonomy", and "competence" (Freidson, 2001; Parson, 1939). By around the turn of the century, the school reform of the 1990s had been fully integrated into the schools' operations. During the same period, "marketisation" had also taken hold in the school system, and society at large. Neo-liberal ideas concerning the control and management of public services became predominant, and ideas about what legitimised professional behaviour also changed (Brown \& Calnan, 2016; Fournier, 1999). The opportunities for teachers to develop in their chosen profession decreased during this period (Agevall et al., 2017; Krantz \& Fritzén, 2017). Gradually, it became clear what problems the school system and the teaching profession were confronted with. At a time when a lack of quality and a lack of equality in the Swedish school system came to take on leading roles in the prevailing discourse, STU added to an already problematic situation by calling for increased transparency, legal security, equality, efficiency, and educational attainment results. Even if the period in question can be characterised by a discursive battle in the field of tension between "a willingness for adaptation" and "a resistance to adaptation", the union's external legitimacy became clearly dependant on systemic demands and the notion of "organisational professionalism" (Evetts, 2009; Jenkins, 2014). When system rationality takes the upper hand (in terms of increased external demands and expectations) over the authority previously inherent to the profession, then there is great danger that the teachers' influence will decrease.

Between 2000 and 2015, a crisis in efficiency and a crisis in legitimacy were clearly apparent in the collective identity. According to the union, these crises also contributed to the impending teacher crisis that now faces Sweden. In the period after 2015, a growing sense of polarisation took place in the social debate, which was accompanied with an increased degree of segregation and more patent shortcomings regarding the question of equality across different Swedish public schools. In response to this, changes in the collective identity were effected that highlighted the teaching profession's norms, values, and responsibility (Sachs, 2001). The union argued that: 
In a democratic society, one does not find silent professions who just quietly perform their work despite the fact that political decisions have problematic consequences. In a democratic society, professions raise their voices and ask critical questions where they are needed-from the politicians. This is the democratic society which we teachers now stand up for. $(L T, 2016$, no.17)

In conclusion, it is quite clear how the teacher's union adapted and defended its position with respect to the prevailing political, economic, and ideological conditions in the social practice (Jenkins, 2014). This has led to a number of contradictions and inconsistencies in the collective identity.

A gradual discursive change is taking place in attitudes about the teaching profession actually is and what it should be. STU has adapted to the policy changes concerning the teachers' knowledge base. However, STU has shown resistance to those policy changes concerning the conditions for school governance and the conditions for teacher's professional work. In its criticism of this state of affairs, STU has highlighted the teachers' negative experiences of this increasing political control of the school system and the worsening conditions for teachers who wish develop in their profession with respect to recognition, emotional engagement, and evaluating and taking responsibility for the work that they do.

We thus observe that the teachers' trade-union has to find a balance between adaptation and showing resistance if it is to gain both external legitimacy and internal legitimacy. Consequently, the collective identity of the union's members is subject to continual change. However, if the union wishes to move forward in its positioning, then it has to act in a more proactive fashion and show greater independence. Crucially, the union's argumentation should be based on the professional conditions that its members work under.

\section{Funding Open access funding provided by Linnaeus University.}

Open Access This article is licensed under a Creative Commons Attribution 4.0 International License, which permits use, sharing, adaptation, distribution and reproduction in any medium or format, as long as you give appropriate credit to the original author(s) and the source, provide a link to the Creative Commons licence, and indicate if changes were made. The images or other third party material in this article are included in the article's Creative Commons licence, unless indicated otherwise in a credit line to the material. If material is not included in the article's Creative Commons licence and your intended use is not permitted by statutory regulation or exceeds the permitted use, you will need to obtain permission directly from the copyright holder. To view a copy of this licence, visit http://creativecommons.org/licen ses/by/4.0/.

\section{References}

Agevall, L., \& Jonnergård, K. (2007). Management by documents-A risk of deprofessionalising? In C. Aili, L.-E. Nilsson, L. G. Svensson, \& P. Denicolo (Eds.), Tension between organisations and profession. Professionals in Nordic public service. (pp. 35-55). Nordic Academic Press.

Agevall, L., Jonnergård, K., \& Krantz, J. (2017). Frihet under ansvar eller ansvar under tillsyn. Om dokumentstyrning av professioner [Freedom under responsibility or responsibility under tranparency? About management by document of professions]. Linnaeus University Press. 
Bascia, N. (2008). What teachers want from their unions. What we know from research. In M. Compton \& L. Weiner (Eds.), The global assault on teaching, teachers, and their unions: Stories for resistance. (pp. 95-108). Palgrave MacMillan.

Bejerot, E., Forsberg Kankkunen, T., \& Hasselbladh, H. (2015). Två decennier av new public management: Arbetsmiljö i skola och sjukvård [Two decades of New Public Management: The work environment in school and health care]. Arbetsmarknad and Arbetsliv, 21(3), 23-41

Bergh, A. (2010). Vad gör kvalitet med utbildning? Om kvalitetsbegreppets skilda innebörder och dess konsekvenser för utbildning [Different meanings of the concept of 'quality' and their consequences for education ]. Örebro Universitet.

Biesta, G. J. J. (2011). God utbildning i mätningens tidevarv [Good education in an age of measurement]. Liber.

Blomgren, M., \& Waks, C. (2009). Lärarna och utbildningsinspektionen-Professionens roll i institutionell omvandling [Teachers and educational inspections-The role of the profession in institutional transformation]. In P. Adolfsson \& R. Solli (Eds.), Offentlig sektor och komplexitet. Om hantering av mål, strategier och professioner [Public sector and complexity. Managing goals, strategies, and professions]. (pp. 227-250). Studentlitteratur.

Bogotch, I. E., Miron, L., \& Biesta, G. J. J. (2007). Effective for what; effective for whom? Two questions SESI should not ignore. In T. Townsend (Ed.), International handbook of school effectiveness and improvement. (pp. 93-110). Springer.

Brante, T., Johnsson, E., Olofsson, G., \& Svensson, L. G. (2015). Professionerna i kunskapssamhället. En jämförande studie av svenska professioner [Professions in the knowledge society. A comparative study of Swedish professions]. Liber.

Bringselius, L. (2018). Inledning. In L. Bringselius (Ed.), Styra och leda med tillit. Forskning och praktik Forskningsantologi från Tillitsdelegationen (SOU 2018:38) [Governance and management with trust. Research and practice. Research anthology from the delegation for trust-based public management]. (pp. 13-38). Erlanders Sverige AB.

Brown, P., \& Calnan, M. (2016). Professionalism, trust and cooperation. In M. Dent, I. Lynn Bourgeault, J.-L. Denis, \& E. Kuhlmann (Eds.), The Routledge companion to the professions and professionalism. (pp. 129-143). Routledge.

Carlbaum, S., Hult, A., Lindgren, J., Novak, J., Rönnberg, L., \& Segerholm, C. (2014). Skolinspektion som styrning [School inspection as control]. Utbildning and Demokrati, 23(1), 5-20

Carlgren, I. (2000). The implicit teacher. In K. Klette, I. Carlgren, J. Rasmussen, H. Simola, \& M. Sundkvist (Eds.), Restructuring Nordic teachers: An analysis of policy texts from Finland, Denmark, Sweden, and Norway. (pp. 313-348). University of Oslo.

Carlgren, I., \& Marton, F. (2001). Lärare av i morgon [Tomorrow's teachers]. Lärarförbundets Förlag.

Chouliaraki, L., \& Fairclough, N. (1999). Discourse in late modernity. Rethinking critical discourse analysis. Edinburgh University Press.

Evetts, J. (2009). The management of professionalism. A contemporary paradox. In S. Gewirtz, P. Mahony, I. Hextall, \& A. Cribb (Eds.), Changing teacher professionalism. International trends, challenges and ways forward. (pp. 19-30). Routledge.

Evetts, J. (2010). Reconnecting professional occupations with professional organisations: Risk and opportunities. In L. Svensson \& J. Evetts (Eds.), Sociology of professions, continental and AngloSaxon traditions. (pp. 123-144). Daidalos.

Evetts, J., Mieg, A. H., \& Felt, U. (2006). Professionalisation, scientific expertise, and elitism: A sociological perspective. In K. A. Ericsson, N. Charness, P. J. Feltovich, \& R. R. Hoffman (Eds.), The Cambridge handbook of expertise and expert performance. (pp. 105-123). Cambridge University Press.

Fairclough, N. (1992). Discourse and social change. Polity Press.

Fairclough, N. (1995). Media discourse. Hodder Education.

Fournier, V. (1999). The appeal to 'professionalism' as a disciplinary mechanism. Sociological Review, 47(2), 280-308

Freidson, E. (2001). Professionalism: The third logic. The University of Chicago Press.

Gustafsson, J. E., Sörlin, S., \& Vlachos, J. (2016). Policyidéer för svensk skola [Policy ideas for the Swedish school system]. SNS Förlag.

Heggen, K. (2008). Profesjon og identitet. In A. Molander \& L. I. Terum (Eds.), Profesjonsstudier [Studies in profession]. (pp. 321-332). Universitetsforlaget.

Ivarsson Westerberg, A. (2016). På vetenskaplig grund. Program och teknologi inom skolinspektion [On a scientific basis. School inspection programs and technology]. Södertörns högskola. 
Jacobsson, B., \& Pierre, J. (2008). Politikens medialisering. Introduktion [Policy medialisation. Introduction]. Statsvetenskaplig Tidskrift, 110(4), 331-334

Jarl, M., \& Rönnberg, L. (2010). Skolpolitik. Från riksdagshus till klassrum [School policy. From Parliament House to the classroom]. Liber.

Jenkins, R. (2014). Social identity. (4th ed.). Routledge.

Jesson, J., \& Simpkin, G. (2007). New Zealand's education reforms. Engendering changes in the teacher unions. International Electronic Journal for Leadership in Learning, 11(22), 1-9

Jonnergård, K., \& Krantz, J. (2017). Tråkigt på jobbet. Dokumentstyrning av revisorer och lärare [Bored at work-Auditors and teachers under management by documents]. Socialvetenskaplig Tidskrift, 24(3-4), 261-279. https://doi.org/10.3384/SVT.2017.24.3-4

Klette, K. (2002). Reform policy and teacher professionalism in four Nordic countries. Journal of Educational Change, 3(3-4), 265-282

Krantz, J., \& Fritzén, L. (2013). Lärarprofessionens kollektiva självbild: Som den framträder i Lärarnas tidning och Pedagogiska magasinet 1990-2010 [The collective self-image of the teaching profession: As it appears in the Teachers' Magazine and the Pedagogic Magazine 1990-2010]. En rapport från Forum för professionsforskning 2013:3Linnaeus University.

Krantz, J., \& Fritzén, L. (2017). From expert to novis? The influence of management by documents on teachers' knowledge base and norms. Professions and Professionalism. https://doi.org/10.7577/ pp. 2113

Lärarförbundet. (1995). Stadgar för Lärarförbundet antagna av kongressen 1995 [Statutes for the Swedish teacher union adopted by the Congress in 1995]. Lärarförbundet.

Lilja, P. (2014). Negotiation teacher professionalism-On the symbolic politics of Sweden's teacher unions. Malmö högskola.

Mausethagen, S. (2013). Accountable for what and to whom? Changing representations and new legitimation discourses among teachers under increased external control. Journal of Educational Change, 14(4), 423-444

Mausethagen, S., \& Smeby, J. C. (2016). Contemporary education policy and teacher professionalism. In M. Dent, I. L. Bourgeault, J.-L. Denis, \& E. Kuhlmann (Eds.), The Routledge companion to the professions and professionalism. (pp. 329-342). Routledge.

Nerland, M., \& Karseth, B. (2015). The knowledge work of professional associations. Approaches to standardisation and forms of legitimisation. Journal of Education and Work, 28(1), 1-23. https:// doi.org/10.1080/13639080.2013.802833

Nilsson-Lindström, M., \& Beach, D. (2013). The professionalisation of the field of education in Sweden: A historical analysis. Professions and Professionalism. https://doi.org/10.7577/pp.560

OECD. (2015). Improving schools in Sweden: An OECD perspective. Paris: Directorate for Education and Skills, OECD. Retrieved from http://oecd.org/edu/school/Improving-Schools-in-Sweden.pdf.

Parson, T. (1939). The professions and social structure. Social Forces, 17(4), 457-467

Persson, S. (2007). Lärarkåren som agent på skolarenan. In J. Pierre (Ed.), Skolan som politisk organisation [The school as a political organization]. (pp. 81-99). Gleerups.

Popiel, K. (2013). Teacher union legitimacy. Shifting the moral center for member engagement. Journal of Educational Change, 14(4), 465-500

Sachs, J. (2001). Teacher professional identity. Competing discourses, competing outcomes. Journal of Educational Policy, 16(2), 149-161

Schrøder, K. C. (2012). Discursive realities. In K. Bruhn Jensen (Ed.), A handbook of media and communication research. Qualitative and quantitative methodologies. (pp. 106-130). Routledge.

Scott, R. W. (2008). Lords of the dance. Professionals as institutional agents. Organisation Studies, 29(2), 219-238

Sjöberg, L. (2010). Lärarprofessionalism på glid. Performativ förskjutning av statlig och lärarfacklig utbildningspolicy [Teacher professionalism adrift. Performative shifts in the State's and teacher union's education policy]. Pedagogisk Forskning i Sverige, 15(1), 18-32

SKL. (2016). Öppna jämförelser, Grundskolan 2016. Tema nyanlända [Open comparisons, Primary school 2016. Theme: 'the newly-arrived']. Sveriges kommuner och landsting.

SKL. (2018). Skolans rekryteringsutmaningar-Lokala strategier och exempel [The school system's recruitment challenges -Local strategies and examples]. Sveriges kommuner och landsting.

Solbrekke, T. D., \& Englund, T. (2011). Bringing professional responsibility back in. Studies in Higher Education, 36(7), 847-861 
SOU. (2014). Staten får inte abdikera-om kommunaliseringen av den svenska skolan. Utredningen om skolans kommunalisering [The state must not abdicate-about the communalization of the Swedish school. An investigation of the school's municipalization]. Regeringskansliet.

Trumberg, A. (2018). Skolval i internationell belysning. In M. Dahlstedt \& A. Fejes (Eds.), Skolan, marknaden och framtiden [The school system, the market, and the future]. (pp. 113-130). Studentlitteratur.

Publisher's Note Springer Nature remains neutral with regard to jurisdictional claims in published maps and institutional affiliations. 